Lowell Gamer MD, Joseph A. Stirt MD, David A. Finholt MD

\title{
Heart block after intravenous lidocaine in an infant
}

\begin{abstract}
A 14-day-old infant received intravenous lidocaine $\left(2 \mathrm{mg} \cdot \mathrm{kg}^{-1}\right)$ at the conclusion of cataract surgery to prevent coughing from tracheal tube stimulation. Within 30 seconds the infant developed high-grade AV heart block and a ventricular rate of 40 . Following brief resuscitation efforts, the patient had a normal cardiac rhythm, blood pressure and respiratory pattern. Intravenous lidocaine may be followed by major disturbances in cardiac rhythm and rate. Cautious titration of small doses should decrease the potential for adverse effects.
\end{abstract}

\section{Key words}

ANAESTHESIA: paediatric; ANAESTHETICS, LOCAL: lidocaine; COMPLICATIONS: arrhythmia, heart block.

Intravenous lidocaine has been advocated to prevent "bucking" or coughing following general anaesthesia with an endotracheal tube. ${ }^{1-3}$ We present a case of heart block and bradycardia following a bolus of intravenous lidocaine given to a 14-dayold infant to minimize reactivity to an endotracheal tube at the conclusion of a general anaesthetic.

\section{Case report}

A two-week-old, three $\mathrm{kg}$ female was admitted for cataract removal from the left eye. She was the product of a full-term uneventful pregnancy. Following delivery via repeat Caesarean section, Apgar scores were eight and nine at one and five minutes, respectively. An otherwise normal physical examination showed bilateral cataracts. Consul-

From the Departments of Anaesthesiology and Paediatrics, University of Virginia Medical Center, Charlottesville, VA.

Address correspondence to: Dr. D.A. Finholt, Department of Anesthesiology, Box 238, University of Virginia Medical Center, Charlottesville, VA 22908. tants in genetics and ophthalmology discovered no underlying disorder and felt the cataracts were idiopathic.

At age six days, the child underwent general anaesthesia for cataract removal from the right eye. No premedication was used and the anaesthetic consisted of enflurane/nitrous oxide in oxygen. Although two episodes of heart rate slowing occurred in response to surgical manipulation, the heart rate never fell below 90 beats per minute. Administration of atropine $0.05 \mathrm{mg}$ IV increased the heart rate to 120 beats per minute each time. Blood pressure remained stable at $45-50 \mathrm{mmHg}$ systolic throughout the procedure. The remainder of the anaesthetic and operation was uneventful.

At age 14 days, the child was readmitted for cataract extraction from the left eye. No premedication was given prior to arrival in the operating room. Atropine $0.1 \mathrm{mg} I \mathrm{M}$ was administered immediately before induction with halothane/nitrous oxide in oxygen.

After anaesthesia induction and intubation, cataract surgery was begun. While receiving one per cent halothane and 70 per cent nitrous oxide in oxygen the patient had a spontaneous respiratory rate of 30-40 breaths/minute, blood pressure of $50 \mathrm{mmHg}$ systolic, and heart rate of $160-170$ beats per minute. After 35 minutes of surgery, halothane was discontinued and when surgery was completed ten minutes later, nitrous oxide was discontinued and 100 per cent oxygen begun.

Lidocaine $6 \mathrm{mg}\left(2 \mathrm{mg} \cdot \mathrm{kg}^{-1}\right)$ was administered IV over five seconds. Approximately 10-15 seconds after lidocaine administration, the heart rate decreased to 90 beats per minute (sinus rhythm). In spite of controlled ventilation, the heart rate continued to decrease to 40 beats per minute. The electrocardiogram showed high-grade AV block.

No change in heart rate or rhythm occurred despite IV administration of atropine $0.1 \mathrm{mg}$, calcium chloride $100 \mathrm{mg}$, and bicarbonate $1 \mathrm{mEq}$. 
Sternal compressions at a rate of $100 / \mathrm{min}$ were begun and lip colour improved. One minute after resuscitation was begun, atropine $0.1 \mathrm{mg}$ and epinephrine $10 \mu \mathrm{g}$ IV were administered. One minute following administration of these drugs, heart rate increased to 155 beats per minute (sinus rhythm), and blood pressure was $90 \mathrm{mmHg}$ systolic. After three minutes of controlled ventilation with 100 per cent oxygen, the patient was moving and breathing spontaneously. A chest roentgenogram showed the endotracheal tube tip to be $1 \mathrm{~cm}$ above the carina. Arterial blood gas analysis ten minutes later, with the child still intubated and breathing 100 per cent oxygen spontaneously, showed: $\mathrm{pH} 7.38, \mathrm{PO}_{2} 215$ $\mathrm{mmHg}, \mathrm{PCO}_{2} 30 \mathrm{mmHg}$, and B.E. $-1 \mathrm{mEq} \cdot \mathrm{L}^{-1}$.

The trachea was extubated and the child taken to the recovery room while breathing 40 per cent oxygen via a hood. Respiratory rate was 32 breaths/ minute, and HR 140-155 bpm. An uneventful recovery period followed, and the child was discharged home the next day.

\section{Discussion}

Intravenous lidocaine $\left(1-2 \mathrm{mg} \cdot \mathrm{kg}^{-1}\right)$ may attenuate cardiovascular and airway responses to intubation at the beginning and end of general anaesthesia. ${ }^{1-3}$ For this reason the practice is now considered routine by many anaesthetists.

Toxicity from lidocaine includes a spectrum of reactions focusing on the central nervous system and the heart. ${ }^{4}$ Lidocaine produces a slight but significant increase in sinoatrial conduction time in patients with sinoatrial dysfunction. ${ }^{5}$ Sinus bradycardia resulting from lidocaine may be due to the development of sinoatrial block. ${ }^{6}$ Lidocaine can induce second or third degree heart block in patients with bundle branch block, ${ }^{7}$ and thus the drug should be used only with extreme caution in the presence. of heart block and bradycardia. ${ }^{8}$

Many reports of bradycardia or heart block following intravenous lidocaine have appeared over the past two decades. ${ }^{7-17}$ All have involved patients who were elderly, had significant heart disease, or were concurrently receiving drugs such as procainamide, quinidine, or digoxin.

Congenital cataracts may arise from a number of aetiologies (intrauterine infections, metabolic and chromosomal disorders, dysmorphic syndromes) that are associated with congenital heart disease. ${ }^{18}$
However, the infant we describe had no evidence of cardiac anomalies or conduction disturbances beyond mild bradycardia coincident with eye manipulation (oculocardiac reflex) in an earlier operation.

In this child, heart rate began to decrease 10-15 seconds after lidocaine $2 \mathrm{mg} \cdot \mathrm{kg}^{-1}$ IV was given, and continued to fall for the next minute until high-grade AV heart block ensued with a ventricular rate of 40 beats per minute.

It is unlikely the bradycardia in our patient was due to vagal stimulation, since the heart rate remained low in spite of atropine administration. Peak arterial plasma lidocaine levels in adults have been shown to occur 60 seconds following a 20-second IV lidocaine injection of $1-1.5 \mathrm{mg} \cdot \mathrm{kg}^{-1}$. This dose, resulting in therapeutic anti-arrhythmic blood levels $\left(2-6 \mu \mathrm{g} \cdot \mathrm{ml}^{-1}\right)$, initially produced levels over four times the maximum accepted therapeutic level, well in the toxic range (mean $26.6 \mu \mathrm{g} \cdot \mathrm{ml}^{-1}$ in 32 patients). ${ }^{19}$ The time course of the heart dysfunction in the case we report above parallels the expected peak blood level of lidocaine.

Animal and human newbom data suggest infants can tolerate the same lidocaine dose as adults. Newbom sheep need the same blood lidocaine concentrations as adult sheep to demonstrate toxic symptoms. ${ }^{20}$ Neonates have an increased total volume of distribution compared with adults, ${ }^{21}$ which may counteract their decreased plasma protein binding of lidocaine. ${ }^{22}$ In fact, one authority has stated "... reducing [lidocaine] dosage in the neonate solely out of concern for toxicity is not justified." 23 This recommendation may need to be tempered.

Although lidocaine-mediated cardiac dysfunction in the neonatal period has been reported only with massive accidental overdose, ${ }^{24,25}$ our patient received a dose $\left(2 \mathrm{mg} \cdot \mathrm{kg}^{-1}\right)$, at the upper limit of recommended dosage when administering lidocaine as an IV bolus to children. ${ }^{26}$ No pharmacokinetic data exist in children for intravenous lidocaine. Extrapolating dosages from adult data is often dangerous. Thus, lidocaine $2 \mathrm{mg} \cdot \mathrm{kg}^{-1} \mathrm{IV}$ in an infant may be an overdose, leading to a toxic effect, rather than an idiosyncratic effect.

Conversely, the newborn conduction system may respond to lidocaine as does the diseased adult conduction system. The cardiac conduction system continues to develop after birth. Both the arterial 
supply and the collagen framework of the sinus node undergo important changes; the His bundle undergoes a molding and shaping with resulting cell death. ${ }^{27}$ All these changes are vital for the morphology of the normal adult conduction system to appear. In addition, newborn rabbit hearts have low epinephrine stores and decreased sympathetic innervation. ${ }^{28}$ Because the newborn has an immature conduction system and sympathetic innervation she may be susceptible to toxicity even from accepted therapeutic doses of lidocaine. Indeed, foetal hearts bathed with therapeutic levels of amide local anaesthetic solutions demonstrate a decreased spontaneous contraction rate and increased $\mathrm{A}-\mathrm{V}$ conduction times. ${ }^{29}$

Halothane may depress A-V conduction. ${ }^{30}$ Drugs such as lidocaine, which decrease conduction through the A-V node, may increase the likelihood of heart block during halothane anaesthesia. ${ }^{3 !}$

Acidosis may have contributed to the potential for A-V block in our patient. Spontaneously ventilating neonates during halothane/nitrous oxide/ oxygen anaesthesia have been shown to exhibit respiratory acidosis. ${ }^{32}$ Foetal hearts bathed in solutions of low $\mathrm{pH}$ (either from increased $\mathrm{PCO}_{2}$ or decreased $\mathrm{NaHCO}_{3}$ ) demonstrate reduced spontaneous contraction rates and prolonged intraventricular conduction velocities. ${ }^{33}$ Lowering the $\mathrm{pH}$ also exaggerates the delayed conduction seen with amide local anaesthetics. ${ }^{29,33}$ Thus, bolus injection of lidocaine in a neonate with possible respiratory acidosis following halothane anaesthesia may account for the unusual arrhythmia we observed.

In summary, lidocaine $2 \mathrm{mg} \cdot \mathrm{kg}^{-1}$ IV was given as a bolus to a 14-day-old infant at the close of general anaesthesia. Sinus bradycardia and highgrade AV block occurred approximately one minute after lidocaine injection and required cardiopulmonary resuscitation. Administration of "therapeutic" lidocaine doses may be followed by major disturbances in cardiac rate and rhythm. Cautious titration of small doses should decrease the potential for toxic effects or idiosyncratic complications.

\section{References}

1 Steinhaus JE, Gaskin L. A study of intravenous lidocaine as a suppressant of cough reflex. Anesthesiology 1963; 24: 285-90.

2 Bidwai AV, Bidwai VA, Rogers CR, Stanley $T H$.
Blood-pressure and pulse-rate responses to endotracheal extubation with and without prior injection of lidocaine. Anesthesiology 1979; 51: 171-3.

3 Gefke $K$, Andersen LW, Friesel E. Lidocaine given intravenously as a suppressant of cough and laryngospasm in connection with extubation after tonsillectomy. Acta Anaesthesiol Scand 1983; 27: 111-2.

4 Zelis $R$. How benign is lidocaine? Chest $1972 ; 61$ : $599-600$.

5 Dhingra RC, Deedwania PC, Cummings $J M$ et al. Electrophysiologic effects of lidocaine on sinus node and atrium in patients with and without sinoatrial dysfunction. Circulation 1978; 57: 448-54.

6 Parameswaran, R, Kahn D, Monheit R, Goldberg $H$. Sinus bradycardia due to lidocaine: clinicalelectrophysiologic correlations. J Electrocardiol 1974; 7: 75-8.

7 Gupta PK, Lichstein E. Chadda KD. Lidocaineinduced heart block in patients with bundle branch block. Am J Cardiol 1974; 33: 487-92.

8 Gianelly $R$, von der Groenben JO, Spivack AP, Harrison $D C$. Effect of lidocaine on ventricular arrhythmias in patients with coronary heart disease. N Engl J Med 1967; 277: 1215-9.

9 Lippestad CT, Forfang K. Production of sinus arrest by lignocaine. $\mathrm{Br}$ Med $\mathrm{J}$ 197I; I: 537.

10 Josephson ME, Caracta AR, Lau SH, Gallagher JJ, Damato AN. Effects of lidocaine on refractory periods in man. Am Heart J 1972; 84: 778-86.

11 Cheng TO, Wadhwa $K$. Sinus standstill following intravenous lidocaine administration. JAMA 1973; 223: 790-2.

12 Lichstein E. Chadda KD, Gupta PK. Atrioventricular block with lidocaine therapy. Am J Cardiol 1973; 31: 277-81.

13 Marriot HJL, Phillips $K$. Profound hypotension and bradycardia after a single bolus of lidocaine. J Electrocardiology 1974; 7: 79-82.

14 Klein HO, Jutrin I, Kaplinsky E. Cerebral and cardiac toxicity of a small dose of lignocaine. $\mathbf{B r}$ Heart J 1975; 37: 775-8.

15 Manyari-Ortega DE, Brennan FJ. Lidocaineinduced cardiac asystole. Chest 1978; 74: 227-9.

16 Grenadier E, Alpan G, Keidar S, Palant A. Respiratory and cardiac arrest after the administration of lidocaine into the central venous system. Eur Heart J 1981; 2: 235-7.

17 Demczuk $R J$. Significant sinus bradycardia following intravenous lidocaine injection. Anesthesiology 1984; 60: 69-70. 
18 Calhoun JH. Cataracts. In: Harley RD, ed. Pediatric Ophthalmology. Philadelphia: Saunders, 1983: 552-3.

19 Roos JC, Dunning AJ. Effects of lidocaine on impulse formation and conduction defects in man. Am Heart J 1975; 89: 686-99.

20 Morishima HO, Pedersen $H$, Minster $M$ et al. Toxicity of lidocaine in adult, newborn, and fetal sheep. Anesthesiology 1981; 55: 57-61

21 Mihaly GW, Moore RG. Thomas J, Triggs EJ, Thomas D, Shanks CA. The pharmacokinetics and metabolism of the anilide local anesthetics in neonates. I. Lignocaine. Europ J Clin Pharmacol 1978; 13: $143-52$

22 Wood $M$, Wood AJJ. Changes in plasma drug binding and $\alpha_{1}$-acid glycoprotein in mother and newborn infant. Clin Pharmacol Ther 1981; 29: 522-6.

23 Singler $R C$. Pediatric regional anesthesia. In: Gregory GA, ed. Pediatric anesthesia. New York: Churchill Livingstone, 1983: 481-518.

24 Sinclair JC, Fox HA, Lentz JF, Fuld GL, Murphy $J$. Intoxication of the fetus by a local anesthetic. N Engl J Med 1965; 273: 1173-7.

25 Matsuki A. Accidental massive lignocaine injection to newborn. Anaesth Intensive Care 1978; 6: 88-9.

26 Olley $P M$. Cardiac arrhythmias. In: Keith JD, Rowe RD, Vlad P, eds. Heart disease in infancy and childhood. New York: MacMillan, 1978: 275-301.

27 James TN. Cardiac conduction system: fetal and postnatal development. Am J Cardiol 1970; 25: 213-26.

28 Friedman WF, Pool PE, Jacobowitz D, Seagren SC, Braunwald $E$. Sympathetic innervation of the developing rabbit heart. Circ Res 1968; 23: 25-32.

29 Andersson KE. Gennser $G$, Nilsson $E$. Influence of mepivacaine on isolated human foetal hearts at normal and low pH. Acta Physiol Scand 1970; 80 (Suppl. 353): 34-47.

30 Atlee JL III, Rusy BF. Halothane depression of A-V conduction studied by electrograms of the bundle of His in dogs. Anesthesiology 1972; 36: 112-8.

31 Maze M, Mason DM Jr. Aetiology and treatment of halothane-induced arthythmias. In: Mazze RI, ed. Inhalation Anesthesiology. Philadelphia: Saunders, 1983: 301-20.

32 Podlesch I, Dudziak R, Zinganell $K$. Inspiratory and expiratory carbon dioxide concentrations during halothane anesthesia in infants. Anesthesiology 1966; 27 : 823-8.
33 Andersson $K E$, Gennser $G$. Nilsson $E$. Influence of acid-base changes on isolated human foetal hearts. Acta Physiol Scand 1970; 80 (Suppl. 353): 20-33.

\section{Résumé}

A la fin d'une chirurgie pour cataracte, un enfant de 14 jours a reçu une injection intraveineuse de lidocaïne (2 $\mathrm{mg} \cdot \mathrm{kg}^{-l}$ ) afin de prévenir la toux provoquée par le tube endotrachéal. En dedans de 30 secondes, l'enfant a développé un bloc $A V$ avec un rythme ventriculaire de 40. Aprés des mancouvres brèves de réanimation, le rythme cardiaque, la pression artérielle ainsi que la respiration retournèrent à la normale. L'injection intraveineuse de lidocaine peut être suivie par des perturbations majeurs dans le rythme et la fréquence cardiaque. La précaution dans le calcul des petites doses a administrer doit diminuer le risque potentiel des effets secondaires. 